of college and research libraries have access to this information.

f. Assuring that cataloging and other organizational procedures are free from prejudicial damage.

g. Assuring that users are trained in the use of new technologies in order that their access to information is not impeded.

$h$. Assuring that the information and library needs of special populations of users, such as older or non-traditional students, those who are nonEnglish speaking, the disabled, students from particular ethnic and social groups, are attended to.

i. Assuring that effective teaching and usage of databases and other access tools provide an understanding of what is included in order for no patron to be deprived of information inadvertently.

j. Assuring the confidentiality of circulation rec- ords, database searching records, and other patronbased records is maintained in order that privacy of library research and usage is respected.

$\mathrm{k}$. Assuring that the library joins with other parts of the parent educational or research institution in participating in public service and outreach programs that address the needs of the broader social community.

Additionally, social responsibility embraces a sensitivity to the practice of the profession with respect to the active recruitment, promotion and retention of minorities, women, and special populations.

While the Task Force does not intend that the above is a definitive statement on social responsibility, its members believe that ACRL may use it as a starting point and in doing so, the organization would be in line with other ALA divisions.

\title{
ACRL actions, June 1989
}

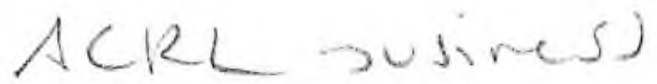

\section{Highlights of the Annual Conference meetings of the ACRL}

Board of Directors.

$\mathbf{T}$

he Board of Directors of the Association of College and Research Libraries met twice during the ALA Annual Conference in Dallas: on June 24, 1989, and June 27, 1989.

\section{Budget}

The Board approved as policy the recommendation of the Budget and Finance Committee that "when an ACRL unit undertakes an activity which generates revenue in excess of expenses, this revenue will revert to the ACRL operating budget."

The Board also voted to express concern to the ALA Executive Board and to the incoming ALA Executive Director, Linda Crismond, regarding excessive delays experienced in receiving monthly financial information on ACRL expenses and reve- nues. A request will also be made to the ALA Executive Board for assistance with questions regarding ACRL's Unrelated Business Income Tax liability.

The Board approved the 1990 budget and 1990 financial plan presented by the Budget and $\mathrm{Fi}$ nance Committee, which shows a deficit of $\$ 74,750$. A full report on the ACRL budget will appear in a future issue of $C \backsim R L$ News.

\section{Discussion groups}

The Board approved a petition for the establishment of an Academic Librarians' Association Discussion Group. The group will be for librarian associations located in individual libraries and is not intended for state-wide associations. 


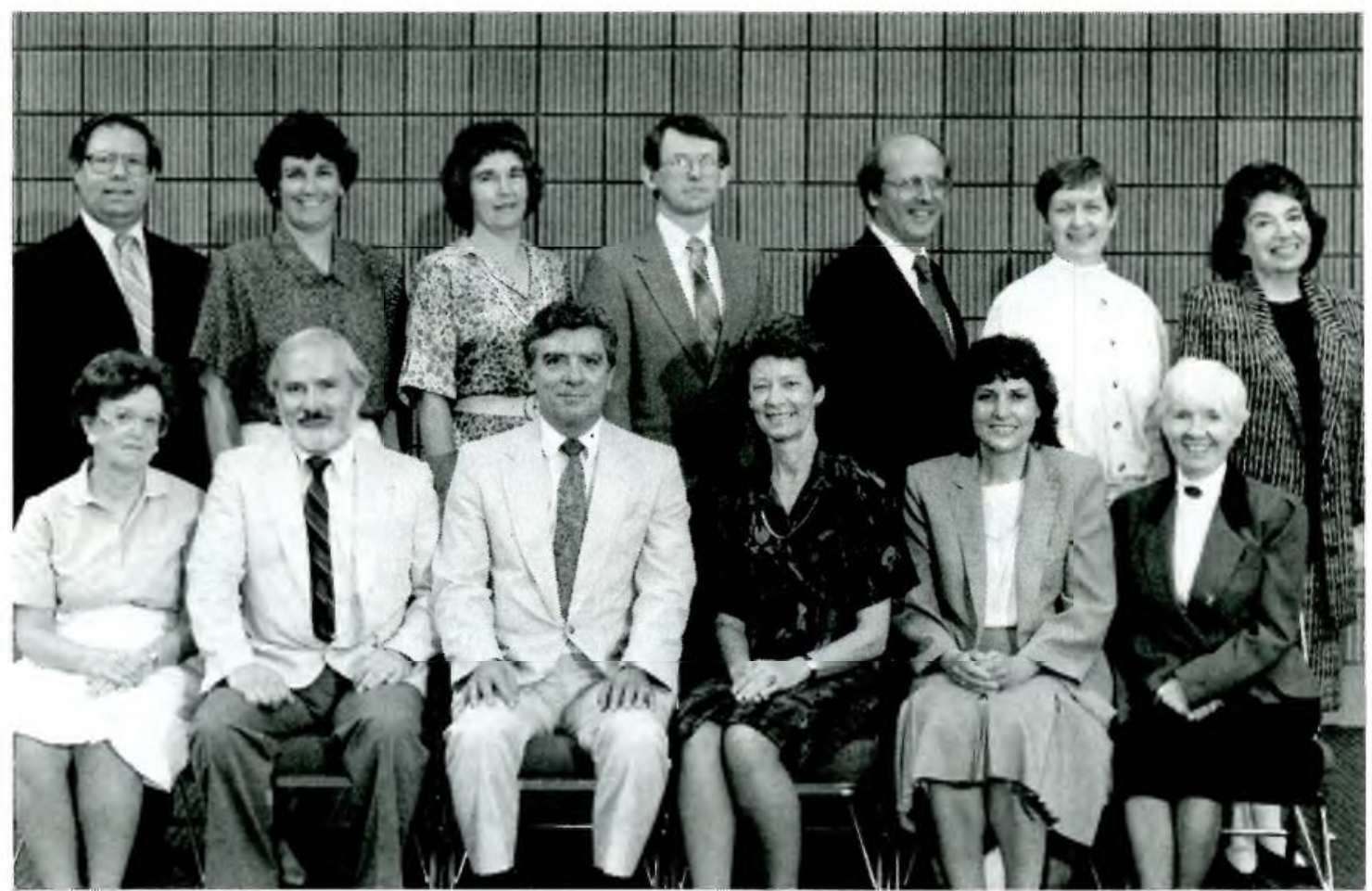

ACRL Board, 1988-89. Back row: Thomas Kirk, Mary Sue Ferrell, Elizabeth Salzer, Larry Hardesty, Peter Malanchuk, Linda Piele, Rochelle Sager. Front Row: Anne Commerton, William A. Moffett, Joseph A. Boissé, Joanne Euster, Anne Beaubien, JoAn S. Segal. Not present: Melvin George.

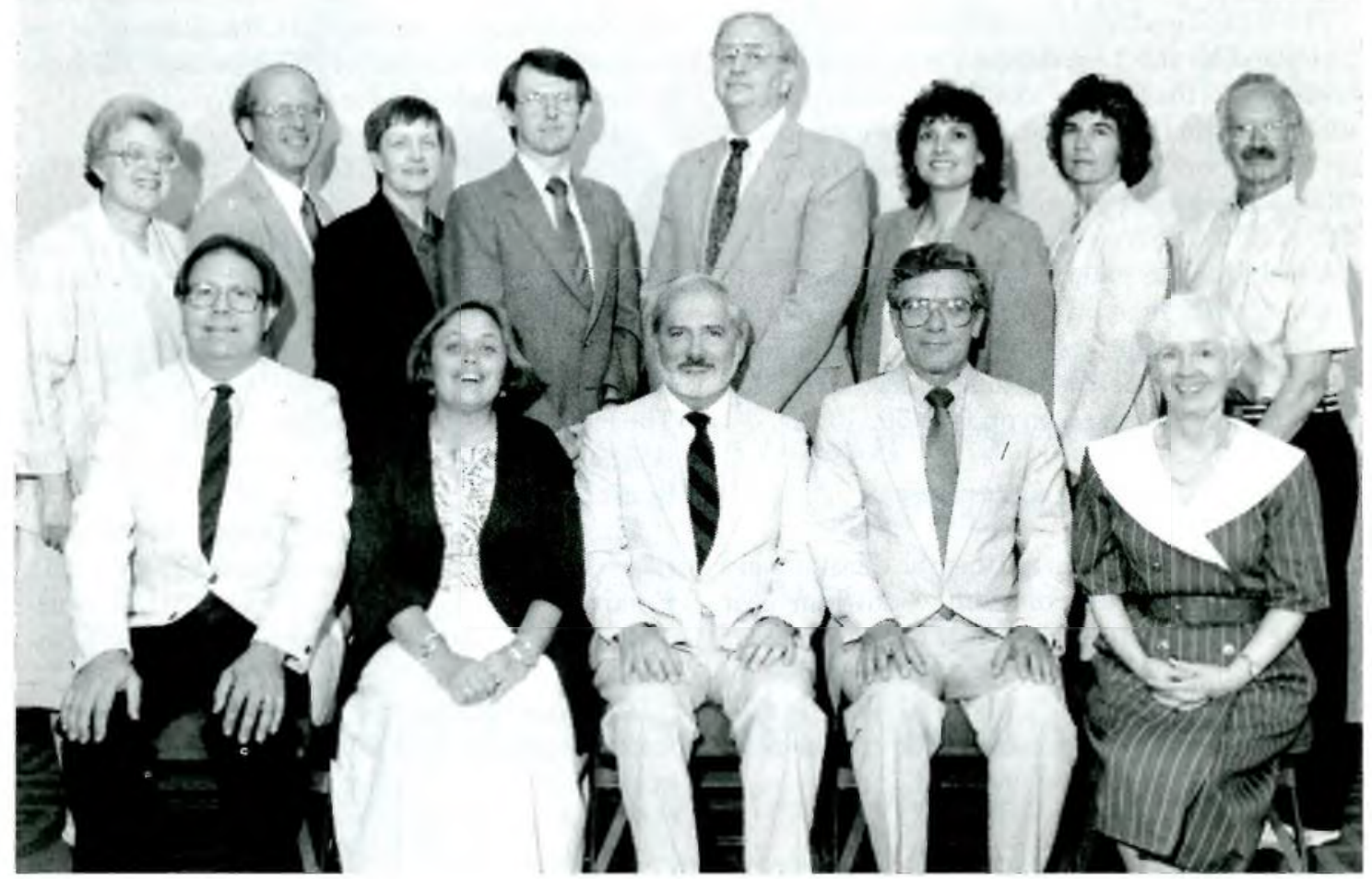

ACRL Board, 1989 90. Back row: Eileen Dubin, Peter Malanchuk, Linda Piele, Larry Hardesty, Melvin George, Anne Beaubien, Elizabeth Salzer, Evan Farber. Front row: Thomas Kirk, Barbara Ford, William A. Moffett, Joseph A. Boissé, JoAn S. Segal. 


\section{Fifth National Conference}

Evan Farber, co-chair of the ACRL Fifth National Conference Executive Committee, reported that the mood of the Committee at its wrap-up luncheon was euphoric. He briefly reviewed the results of the participant evaluation forms and noted that the preliminary budget projected indicated $\$ 84,000$ excess of revenues over expenses. Farber stated that the Cincinnati site proved excellent, that the local arrangements committee was outstanding, and that he had heard from veteran conference goers that the conference was one of the best they had attended.

The Board extended a formal vote of thanks to the Cincinnati Conference Committee for their outstanding work.

\section{Information literacy}

The Board established information literacy as the planning priority for 1990/1991. A report on the "Symposium on Information Literacy and Education for the 21st Century: Toward an Agenda for Action" was referred to BIS, CJCLS and EBSS for their review and recommendations. JoAn Segal explained that the symposium was an effort between AASL and NCLIS.

\section{Legislation}

The Board endorsed the following resolutions submitted by the Legislation Committee: reauthorization of the Paperwork Reduction Act; OMB's rulemaking on Dissemination of Information Policy; the report, Informing the Nation, from the Office of Technology Assessment; reauthorization of the Library Services and Construction Act; and gratitude for the planned funding of the White House Conference on Library and Information Services. For a full account of the relevance of these resolutions, see the article by Harold B. Shill and Sandra K. Peterson on pp.649-56.

\section{Operating agreement}

President Boissé reported that the divisions and COPES had agreed to a compromise on a four-year phasing in of overhead payments on conferences and workshops. He said he was pleased that an agreement had been reached and that he had established a task force to examine the impact of the new operating agreement on ACRL.

\section{Performance measures}

The Board extended the term of the ad hoc Committee on Performance Measures until the
1990 Midwinter Meeting. Virginia Tiefel, committee chair, reported that the measures were being tested a draft of the manual was under review. The final edition will be submitted for ACRL Executive Committee approval in the fall. The goal is to have the manual published before the 1990 ALA Conference.

\section{Publications}

The Board established an ad hoc Non-Serials Publications Editorial Board to advise the ACRL staff publications officer on titles for publication.

\section{Sections}

The Board approved a petition for the establishment of the Afro-American Studies Librarian Section (AFAS) and dissolved the Black Studies Discussion Group. The discussion group, chaired by Clarence Chisholm, has been meeting for six years and has grown to more than 90 members.

\section{Standards and guidelines}

The Board rescinded the ACRL Activity Model for the 1980s, which has been superseded by the ACRL strategic planning process.

The Board approved: "ACRL Guidelines for the Preparation of Policies on Library Access"; "Guidelines for Academic Status for College and University Librarians"; and the "ACRL Statement on Licensing and Certification of Librarians." All three items will be published in $C \dot{U} R L$ News.

\section{Task forces}

The Board received final reports from the task forces on Professional Ethics, on International Relations, and on ACRL and Social Responsibilities. The latter's definitions of social responsibilities appears elsewhere in this issue (pp. 695-96). The Planning Committee will now consider whether standing committees for each of these areas need to be established.

The terms of the following task forces were extended: Librarians as Instructors (1990 Annual), Financial Development (1990 Annual), Historically Black Colleges and Universities (1991 Annual).

The Board discharged the Small College Assessment Program task force so the group could reform as a task force of the College Libraries Section. The new CLS group will work with the Associaton of Research Libraries' Office of Management Studies to co-sponsor ARL's Planning Process for Small Academic Libraries. 


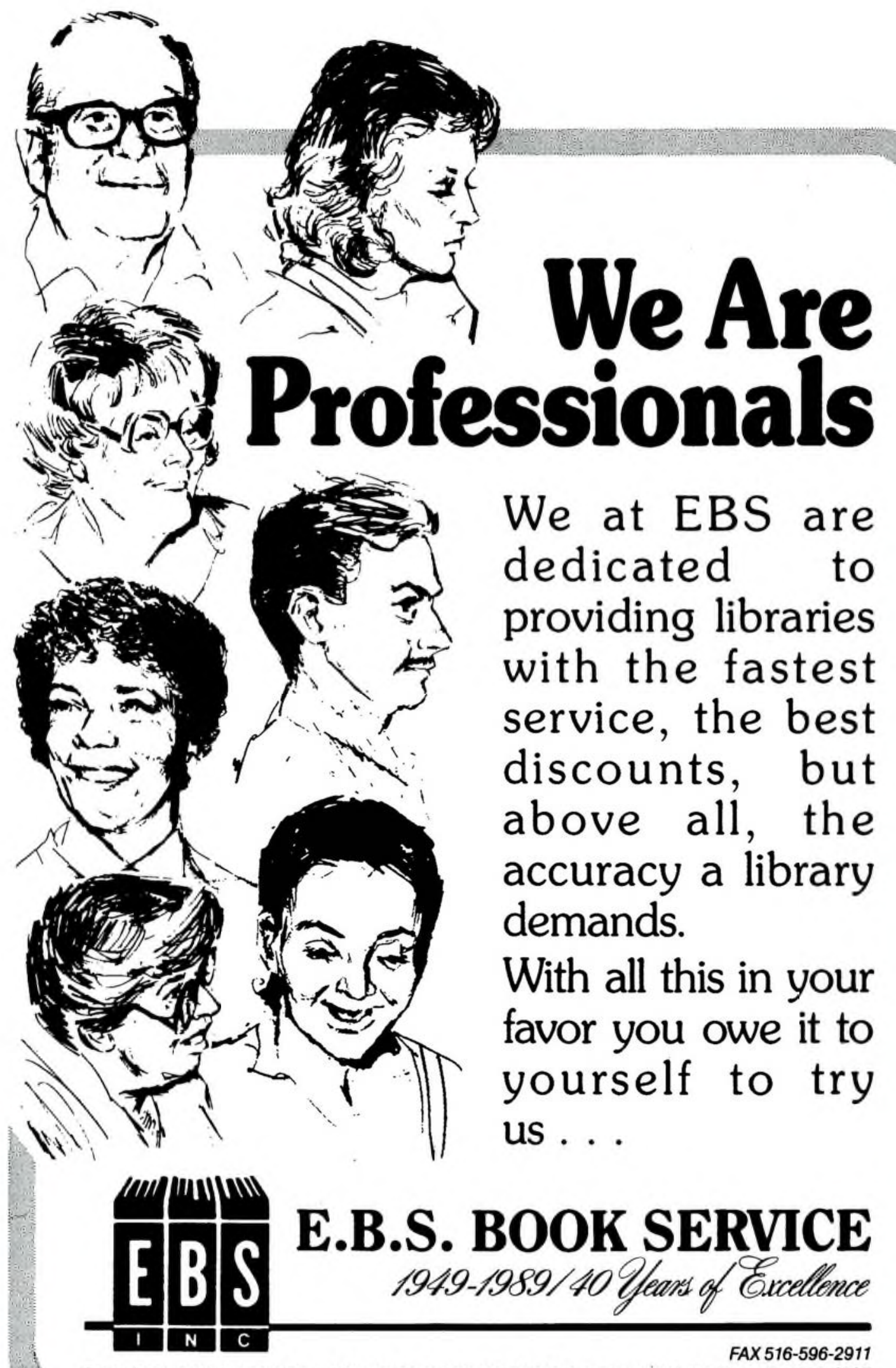

E.B.S. INC. BOOK SERVICE - 290 BROADWAY, LYNBROOK, NEW YORK 11563 - 516-593-1207 


\section{Essential Library Resources}

\section{World Guide to Libraries}

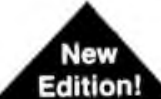

Ninth Edition

Edited by

Helga Lengenfelder

"The most comprehensive of all guides to libraries."

- American Notes and Queries

This trusted guide is the definitive directory of the international information community. World Guide to Libraries, Ninth Edition provides detailed listings of over 39,000 libraries (1,300 new to this edition!) in 167 countries-including national, federal, university and public libraries, special, governmental, parliamentary, religious and business libraries. Each entry provides the library name, address and telex number; special collections and

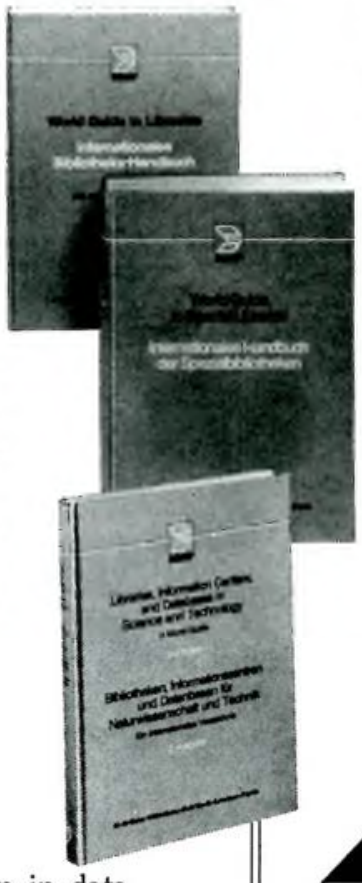
statistics on holdings; participation in data networks; and more. Arranged for easy access by continent and country, then by city and type of library, this unique resource is a must for librarians and scholars.

(Handbook of International Documentation and Information, Volume 8)

May 1989/3-598-20539-2/1,275 pp./\$275

Standing Order Price: $\mathbf{\$ 2 6 1 . 2 5}$

\section{World Guide to Special Libraries}

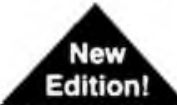

\section{Second Edition}

Edition:

\section{Edited by Helga Lengenfelder}

“.... an extremely useful tool .... should be a part of public and academic library collections..."

- American Reference Books Annual The long-awaited revised and expanded edition of this acclaimed directory includes entries for more than 32,000 libraries in 160 countries. All listings are divided into 5 major categories-General, Humanities, Social Sciences,
Medicine and Life Sciences, and Science and Technology - then within these categories by country and city. Each entry provides library name, address, telephone and telex numbers; special holdings and collections, and membership in specialist confederations, and more. (Handbook of International Documentation and Information, Volume 17)

November 1989/3-598-22230-0/1,200 pp. \$198 tentative/Standing Order Price: \$188 tentative

\section{Libraries, Information Centers and Databases in Science and Technology A World Guide}

New Second Edition

Edition! Edited by Helga Lengenfelder

"The directory is well-organized; the type is readable; the contents are informative and current."

- Information Processing and Management This invaluable international directory covers libraries, on-line databases and documentation centers in all areas of pure and applied sciences. The second, completely revised edition provides current information for independent specialized national libraries, technical college libraries, institute and seminar libraries, as well as those of research organizations, museums, archives, scientific associations and international organizations. Listing institutions by country, the directory includes some 13,500 special libraries in 141 countries; 200 information and documentation centers; and over 300 database producers. 1988/3-598-10757-9/697 pp. $\$$ 195

Standing Order Price: $\mathbf{\$ 1 8 5 . 2 5}$

For fastest ordering, call TOLL-FREE 1-800-521-8110 